\title{
AUREOMYCIN IN TRACHOMA*
}

BY

\author{
A. J. BOASE \\ Uganda
}

IN an earlier communication (Boase, 1950) it was suggested that aureomycin (Lederle) drops were very effective in the treatment of trachoma. That opinion was based on a small number of cases, none of whom has reappeared with a relapse. The present report deals with 36 cases, the last four included being at a disadvantage as the supply of aureomycin gave out after only three days' treatment. Twenty cases received drops only, ten received drops and oral capsules, and six oral capsules only. The drops, made up by dissolving the powder in distilled water, were administered at intervals varying from one to four hours. There were no complaints of irritation (Ainslie, 1950). It was found that 2-hourly intervals were the most convenient for the nursing staff, allowing four or five instillations a day. No treatment was given at night. Capsules were given three times a day in eleven cases, and five times a day in five cases. With the exception of four Asiatics, the patients were natives of Uganda and were treated in hospital, the longest in-patient stay being 22 days and the shortest four days. In four cases $(20,21,23$, and 25) treatment was curtailed in favour of a bilateral tarsectomy. The chief particulars are tabulated overleaf; four cases $(7,11,17$, and 20) are given in detail.

\section{Case Histories in Detail}

Case 7.-(No. 582) Male, aged 41. Admitted January 25, 1950. Photophobia and lacrimation for one month. Fine papillary hypertrophy and many follicles. Early active pannus. Aureomycin drops 2-hourly. February 1, symptom-free, no macroscopic evidence of trachoma, says he is cured and asks discharge. Total days treated 7. Assessment on discharge-cured.

Case 11.-Asiatic female, aged 18. First seen in November, 1949, with the complaint that her eyes had been sore for some time, and that the left had been very bad for three weeks. She had had much treatment from different doctors. Left eye showed a thick succulent pannus with a trachomatous ulcer at its edge, many follicles and fine papillary hypertrophy. Right eye was fairly quiet with few follicles and $\frac{1}{5}$ micro-pannus. I treated her regularly with paintings of albucid, twice with silver nitrate, and a course of sulphadiazine. The left eye was atropinized. She ceased attending after one month and was not seen again until January 30 when she said she had been to Nairobi and had been treated there. She was now markedly photophobic and the left eye had a pronounced droop. The ulcer had recurred and was much larger than in November (it had not entirely ceased to stain under my earlier treatment). Pannus had extended and was now about $\frac{1}{3}$. There were confluent blebs on the transition fold. Right eye showed little change. She was given a $5 \mathrm{ml}$. bottle of aureomycin and told to use the drops "frequently." A message on February 1 informed me that she

* Received for publication June 6. 1950. 
TABLE

Chief Particulars of 36 Cases of Trachoma treated with Aureomycin.

\begin{tabular}{|c|c|c|c|c|c|c|c|}
\hline \multirow{2}{*}{$\begin{array}{c}\text { Case } \\
\text { No. }\end{array}$} & \multirow{2}{*}{$\operatorname{sex}$} & \multirow{2}{*}{ Age } & \multirow{2}{*}{$\begin{array}{l}\text { Length of } \\
\text { History }\end{array}$} & \multicolumn{3}{|c|}{ Treatment } & \multirow{2}{*}{$\begin{array}{l}\text { Assessment on } \\
\text { Discharge }\end{array}$} \\
\hline & & & & Method & Dosage & $\begin{array}{c}\text { Duration } \\
\text { (days) }\end{array}$ & \\
\hline 1 & $q$ & 30 & 1 year+R.L. & $\mathrm{D}$ & hourly & 20 & improved \\
\hline 2 & $\sigma$ & 45 & $\begin{array}{l}\text { R. } 1 \text { month } \\
\text { L. normal }\end{array}$ & $\mathrm{D}$ & hourly & 12 & improved \\
\hline 3 & q & 9 & vague but long & $\mathrm{D}$ & hourly & 22 & improved \\
\hline 4 & $\hat{\sigma}$ & 32 & 1 month & $\mathrm{D}$ & $\begin{array}{c}\text { hourly } \\
\text { atropine to } R .\end{array}$ & 12 & improved \\
\hline 5 & $q$ & 8 & 2 years & D & hourly & 19 & cured \\
\hline 6 & 3 & 10 & longr & D) & 2-hourly & 7 & improved \\
\hline 7 & $\hat{0}$ & 41 & 1 month & 1) & 2-hourly & 7 & cured \\
\hline 8 & $\widehat{\sigma}$ & 30 & 2 weeks & D) & 2-hourly & 12 & cured \\
\hline 9 & $\hat{\jmath}$ & 23 & 5 months & I) & $\begin{array}{c}\text { 3-hourly } \\
\text { atropine to I. }\end{array}$ & 7 & improved \\
\hline 10 & $\hat{\sigma}$ & +8 & 2 weeks & $\therefore$ & $\begin{array}{c}3 \text { times daily } \\
\text { no local } \\
\text { treatment }\end{array}$ & 7 & cured \\
\hline 11 & ? & 18 & 3 months & I) & $\begin{array}{l}\text { "frequent " } \\
\text { (out-patient } \\
\text { treatment) }\end{array}$ & 1.5 & cured \\
\hline 12 & $\hat{0}$ & 25 & 5 months & $\begin{array}{l}\text { I) } \\
S\end{array}$ & $\begin{array}{c}3 \text {-hourly } \\
3 \text { times daily }\end{array}$ & 7 & improved \\
\hline 13 & 3 & 35 & 10 years & D) & 3-hourly & 12 & improved \\
\hline 14 & $\hat{o}$ & 30 & 7 years & $\begin{array}{l}\mathrm{D} \\
\mathrm{S}\end{array}$ & $\begin{array}{l}3 \text { times daily } \\
3 \text { times daily }\end{array}$ & 5 & improved \\
\hline 15 & $\hat{0}$ & 13 & $\therefore$ months & $\stackrel{\mathrm{D})}{S}$ & $\begin{array}{c}3 \text {-hourly } \\
3 \text { times daily }\end{array}$ & 12 & cured \\
\hline 16 & q & $4 \frac{1}{2}$ & $\begin{array}{l}\text { L. } 1 \text { year } \\
\text { R. normal }\end{array}$ & 1 & 3-hourly & 14 & cured \\
\hline 17 & $\hat{\sigma}$ & 30 & 3 weeks & $\mathrm{D}$ & 4-hourly & 7 & cured \\
\hline 18 & $\hat{\sigma}$ & 17 & 1 year & $\begin{array}{l}\mathrm{D} \\
\mathrm{S}\end{array}$ & $\begin{array}{c}\text { 3-hourly } \\
3 \text { times daily }\end{array}$ & 7 & improved \\
\hline 19 & 9 & 12 & long & $\mathrm{D}$ & 2-hourly & 8 & improved \\
\hline 20 & $\hat{\sigma}$ & 35 & 1 year $\div$ & $\mathrm{D}$ & $\begin{array}{c}\text { 2-hourly } \\
\text { ilateral tarsecto }\end{array}$ & my & no change \\
\hline
\end{tabular}


TABLE-continued

\begin{tabular}{|c|c|c|c|c|c|c|c|}
\hline \multirow{2}{*}{$\begin{array}{l}\text { Case } \\
\text { No. }\end{array}$} & \multirow{2}{*}{ Sex } & \multirow{2}{*}{ Age } & \multirow{2}{*}{$\begin{array}{l}\text { Length of } \\
\text { History }\end{array}$} & \multicolumn{3}{|c|}{ Treatment } & \multirow{2}{*}{$\begin{array}{l}\text { Assessment on } \\
\text { Discharge }\end{array}$} \\
\hline & & & & Method & Dosage & $\begin{array}{c}\text { Duration } \\
\text { (days) }\end{array}$ & \\
\hline 21 & $\hat{\sigma}$ & 60 & long & $\begin{array}{ll}\mathrm{D} \\
\mathrm{bi}\end{array}$ & $\left\{\begin{array}{c}\text { 2-hourly } \\
\text { atropine } \\
3 \text { times daily } \\
\text { lateral tarsecto }\end{array}\right.$ & my & improved \\
\hline 22 & 우 & 20 & acute & S & 5 times daily & 7 & cured \\
\hline 23 & ㅇ & 43 & 10 years & $\begin{array}{ll}\mathrm{S} & \\
\mathrm{D} & \\
& \\
& \mathrm{bi}\end{array}$ & $\begin{array}{c}5 \text { times daily } \\
2 \text {-hourly } \\
\text { lateral tarsecto }\end{array}$ & my $3+$ & improved \\
\hline 24 & 우 & 50 & long & $\mathrm{S}$ & \begin{tabular}{|c|}
5 times daily \\
no local \\
treatment
\end{tabular} & 5 & improved \\
\hline 25 & $\hat{\sigma}$ & 15 & long & $\begin{array}{ll}\mathrm{S} & \\
& \mathrm{ta}\end{array}$ & $\begin{array}{l}5 \text { times daily } \\
\text { rsectomy later }\end{array}$ & 5 & improved \\
\hline 26 & ㅇ & 7 & 1 year - & D & 2-hourly & 17 & improved \\
\hline 27 & ㅇ & 11 & 3 years & $\begin{array}{l}\mathrm{S} \\
\mathrm{D}\end{array}$ & $\begin{array}{l}3 \text { times daily } \\
2 \text {-hourly }\end{array}$ & $\begin{array}{l}7 \\
5\end{array}$ & improved \\
\hline 28 & $q$ & 14 & 2 years & $\begin{array}{l}\mathrm{S} \\
\mathrm{D}\end{array}$ & $\begin{array}{l}3 \text { times daily } \\
2 \text {-hourly }\end{array}$ & $\begin{array}{l}4 \\
5\end{array}$ & improved \\
\hline 29 & \& & 4 & 2 years & $\mathrm{D}$ & 2-hourly & 7 & improved \\
\hline 30 & q & 33 & 2 weeks & $\begin{array}{l}\mathrm{S} \\
\mathrm{D}\end{array}$ & $\begin{array}{l}3 \text { times daily } \\
\text { 2-hourly }\end{array}$ & 7 & improved \\
\hline 31 & q & 8 & 6 months & $\mathrm{D}$ & frequent & 15 & $\begin{array}{c}\text { doubtful } \\
\text { improvement }\end{array}$ \\
\hline 32 & ㅇ & 16 & 1 week & $\mathrm{D}$ & 2-hourly & 5 & improved \\
\hline $33^{*}$ & $\pi$ & 20 & 2 years & $\mathrm{D}$ & 2-hourly & 3 & improved \\
\hline $34 *$ & 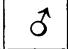 & 32 & 2 years & $\mathrm{D}$ & 2-hourly & 3 & no change \\
\hline $35 *$ & $\pi$ & 7 & 1 month & $\mathrm{S}$ & 3 times daily & 5 & improved \\
\hline $36^{*}$ & $\widehat{0}$ & 36. & acute & $\mathrm{S}$ & $\begin{array}{l}3 \text { times daily } \\
\text { ( } 2 \text { capsules })\end{array}$ & 5 & not improved \\
\hline
\end{tabular}

$\mathrm{D}=$ drops. $\mathrm{S}=$ systemic : the amount of aureomycin given was one capsule per dose, except where otherwise indicated.

* In Cases 33 to 36 the available supply of aureomycin ran out so that treatment could not be completed.

was much better; on February 6 she was smiling, happy, and symptom-free. The left eye is white, the ulcer does not stain, the pannus is definitely regressing. Follicles are not seen, there are still some small blebs on left transition fold. She was given a second bottle of aureomycin, and on February 14 said she was cured. Apart from a slight droop of the left upper lid and attenuated pannus there are no signs of trachoma. 
Total days treated, 15. Assessment on discharge-cured.

Note: Since it is said that aureomycin loses its potency after 48 hours the period of effective treatment in this case is only four days.

Case 17.-(No. 1120) Male, aged 30. Admitted February 20 with three weeks' history of intense photophobia and profuse lacrimation, has to be led by a friend. Upper tarsi crowded with follicles, rich succulent $\frac{1}{5}$ pannus. Aureomycin capsules, one three times daily, drops 4-hourly.

February 22, eyes open, says he has no discomfort.

February 24, says he is cured and wants to go. Capsules stopped. February 27, lids perfectly normal, pannus attenuated to a mere fringe of vessels seen with difficulty with the slit-lamp.

Total days treated, 7. Assessment on discharge-Cured.

Case 20.-(No. 1261) Male, aged 35. Admitted February 27, 1950. History over one year. Marked ptosis, gross papillary hypertrophy with a network of pigment and early Arlt scarring. Total macro-pannus with large vessels from all sides. Aureomycin drops 2-hourly. March 6, thinks he is a little better but is not enthusiastic. Objectively, the papillary hypertrophy appears less gross but otherwise there is no real change. Treatment was stopped and a bilateral tarsectomy performed.

Inclusion Bodies. - The finding of inclusion bodies may be indispensable for diagnosis where this is in doubt, but in a country so heavily infected as Uganda it has only an academic interest, and to make it a sine qua non for diagnosis is comparable to insisting on recognition of the spirochaete before embarking on an antiyaws campaign. In this series conjunctival scrapings were examined in practically all the cases before treatment, but since in a one-man team the time factor is relentless the scrutiny given was hardly sufficient to say with confidence that inclusion bodies were absent. The most that can be said is that they were not found after inadequate search. The positive cases are ascribed more to early good luck than to diligent perseverance.

Excised Tarsal Plates.-The histopathology is typically that of trachoma. In all the specimens there is a profusion of mast cells.

Case 20.-Deep epithelial penetration with large lacunar formations. Marked infiltration, plasma cells predominating, follicular grouping in parts. Much fibrous tissue permeates the mucosa; it is difficult to distinguish the transition from the tarsus which is itself infiltrated with many spindle-shaped cells.

Case 21.-The infiltrated mucosa is thick, about half the thickness of the tarsus from which it is clearly demarcated, though here and there strands of fibrous tissue lead through to the surface. The tarsus is very clean with practically no infiltration; the Meibomian glands are distinct. Deep lacunar penetration of the epithelium reaching in places to the tarsus, surface cells flattened and eroded in parts. Fine pigment granules are seen among the surface cells and accompanying the inward proliferations in a spidery manner. There are no classical follicles. The infiltration shows a preponderance of plasma cells.

Case 23.-The epithelium is thin and flattened with blunt club-shaped inward penetration while some columns go deeper to form lacunae or pseudo-glands. Meibomian glands very distorted and in parts obliterated. No classical follicles. Plasma cells predominate in the infiltration. Despite the clinical findings there is nothing to distinguish the two specimens.

Case 25.--In one tarsus the mucosa is very thin, in the other it is much thicker. Surface cells are flattened. Infiltration is moderate and is permeated by fibroblasts and fibrous tissue. No classical follicles. Capillaries dilated. Meibomian glands very clear. 


\section{Discussion}

The most striking effect of treatment with aureomycin is the rapid relief of the subjective symptoms of lacrimation and photophobia. If it did nothing else the drug would earn an undisputed place in the armamentarium of the trachomatologist.

But does it cure trachoma? What do we mean by a "cure"? In a disease of such remorseless endurance the criterion of this is difficult to assess. Every trachomatologist of experience must surely have had not a few of his "cured" cases return in later years for the relief of trichiasis. Yet the stimulus to form scar tissue presumably lies in persistence of the noxious influence, for Nature as a rule is not prodigal in repair; who knows but that the common keloid will one day admit an aetiology at present undreamt of ? Nevertheless it is generally accepted that in the absence of other signs of activity a smooth tarsus indicates freedom from infectivity, at least from a public health point of view.

By this standard nine of the cases in this series are passed as cured. Of the remainder the majority showed a marked improvement. There is some evidence $(10,15,16,32,35)$ that resolution progresses after cessation of treatment. It is therefore not improbable that some of those classified as impioved might later be put into the category of the cured. Unfortunately native patients do not re-attend without a special reason, which is usually persistence of symptoms. Case 10 is an example; this man would certainly not have returned had his wife not become ill. Yet although on discharge he was only considered improved, three weeks later a fortuitous examination found him cured.

From the histological aspect there is little evidence in the excised tarsi to suggest that aureomycin treatment is likely to lead to a rapid reversal in the tissue changes. Nor should this be expected, for from their nature it would seem that time alone could effect a restitutio ad integram. Furthermore, of the cases thus examined none had progressed far towards the standard of clinical cure accepted above. In this connection it is of interest to record the pathologist's report on Case 3 of my original series (Boase, 1950), for which I am indebted to Dr. Norman Ashton, Director of the Department of Pathology, Institute of Ophthalmology, London :

Sections show rather thickened tarsal plates which, on the conjunctival surface, show dense infiltration with round cells and plasma cells of the adenoidal layer of the conjunctiva. Typical follicles are present in the specimen taken from the right eye. Pseudo-glandular formation is present in all sections. No inclusion bodies have been found in the epithelial cells. The only effect which histological examination might attribute to the treatment given is the lack of infiltration in the epithelial surface itself which looks unusually "clean" in some areas.

It remains to be added that the four specimens of the present 
series were examined for me by Dr. E. S. Horgan, Director of the Virus Research Institute, Uganda, who has kindly informed me that he could find no inclusion bodies.

\section{Conclusion}

Whether or not aureomycin actually cures trachoma, I am satisfied that it does produce a dramatic ameliorative effect the like of which I have not seen before with any other treatment in a long experience of trachoma in a particularly virulent form. My experience with the sulphonamides has been disappointing; they give improvement up to a point but never a cure. Penicillin is useless except as an adjuvant. But the full benefit of aureomycin is best appreciated in contrast with the older classical treatments :

Under vigorous daily treatment by mechanical means, followed by the daily application of various drugs, most ordinary cases of $\mathrm{Tr}$. IIa can be converted into the stage Tr. III in about fifteen days (MacCallan, 1936).

The copper sulphate treatment should be continued daily until the disease has been completely cured. This may take from one to six years or more (Lindner, 1936).

The disease finally subsided after some months of energetic mechanical treatment (Loewenstein, 1945, writing of two cases under observation from their inception).

What patient would not prefer to use some innocuous drops, even, if necessary, for "one to six vears or more"?

\section{Postscript}

After the foregoing case reports were written I saw Case 8 again, on April 24. A schoolmaster from an outlying rural school, he had come to Kampala for a conference. He told me that his eyes had been quite well until about a week ago when they had started to smart and itch. This was annoying but in no way incapacitating, and he was sure it was quite different from the trouble of three months ago. Examination showed a mild catarrhal conjunctivitis with slight sticky mucoid secretion, but the moderately injected tarsi showed a few unquestionable very small follicles. The slit-lamp revealed only a few attenuated vessels, certainly no active pannus.

I feel that these follicles must be regarded as evidence of active trachoma, but whether this is a relapse or a fresh infection I cannot say. Would symptoms of a relapse not have occurred earlier than three months after an apparent cure? His environment is in favour of a fresh infection, for in any rural school in Uganda one expects to find a fair proportion of infected children.

\section{REFERENCES}

Bonse, A. J. (1950). British Journal of Ophthalmolosy, 34, 35.

Ainslie, D. (1950). Ibid., 34, 41.

MacCallan, A. F. (1936). "Trachoma", p, 17. Butterworth.

LINDNER, K. (1936). In Berens, C., "The Fye and its Diseases", p. 433. Saunders, Philadelphia.

Loewenstein, A. (1945). Amer. J. Ophthal., 28, 282. 